Feature Article

\title{
Pterocarpus santalinus (Red Sanders) an Endemic, Endangered Tree of India: Current Status, Improvement and the Future
}

\author{
A.N. Arunkumar ${ }^{*}$ and G. Joshi \\ Tree Improvement and Genetics Division, Institute of Wood Science and Technology, Bangalore, India
}

\begin{abstract}
Pterocarpus santalinus (Family - Fabaceae) popularly known as Red Sanders is an endemic species confined to Southern parts of Eastern Ghats of India specially in Andhra Pradesh. Heartwood of Red Sanders has high demand in domestic as well as international market and the wavy grained wood is valued. Along with its extensive use in furniture, the red dye obtained from the wood is used as colouring agent for textile, medicine and food. The heartwood can accumulate various elements and rare earth elements like strontium cadmium, zinc, copper and uranium. The wood has different uses in traditional and folklore medicines and is used for the treatment of diabetes, prickly heat, skin diseases and for various other ailments. A number of studies have been carried out to anatomically and phenotypicaly screen wavy grain at seedling stage. Morphological variability and genetic diversity studies reveal that Red Sanders harbours enormous variability. Though, macro and micro propagation protocol have been developed, further refinement is required for mass propagation. Andhra Pradesh Forest Department has also initiated different activities under tree improvement programme. Considering the wood demand, restricted distribution, slow regeneration, illegal harvest, trade and habitat destruction, the species has been categorized as endangered by International Union for Conservation of Nature and has been listed in Convention on International Trade in Endangered Species of Wild Fauna and Flora and is also classified as a "reserved tree" under the Andhra Pradesh Preservation of Private Forest Rules, 1978. To revive the past glory of this valuable species, Government agencies, farmers, entrepreneurs and policy makers have to join hands for its protection, sustainable utilization and conservation.
\end{abstract}

Key words: Pterocarpus santalinus, conservation, Red Sanders, tree improvement

\section{Introduction}

Pterocarpus is a well recognised genus of trees and woody climbers distributed through out the world in three tropical regions, i.e., Neotropics, tropical Africa and Indomalaya (Indian subcontinent and Malay Peninsula/Archipelago). It consists of 35 to 40 species (Klitgaard and Lavin, 2005) but is estimated up to 60 species (Chauhan and Vijendra Rao, 2003). Pterocarpus has gained popularity globally for its ethnomedicinal uses and valuable bioactive compounds and the importance of this genus can be appreciated by the study carried out by Saslis-Lagoudakis et al. (2011) to enable the application of community phylogenies in bioscreening, and also shedding light on the processes of shaping cross cultural ethnomedicinal patterns. There are only four species found in India, Pterocarpus

\footnotetext{
*Correspondence: arun@icfre.org

Tel: +918022190156

ISSN 2235-9370 Print/ISSN 2235-9362 Online (C) University of Sri Jayewardenepura
} 
dalbergioides, $P$. indicus, $P$. marsupium and $P$. santalinus. Out of these four species, International Union for Conservation of Nature (IUCN) has listed $P$. indicus and $P$. marsupium as vulnerable and $P$. santalinus as endangered. $P$. dalbergioides, an endemic species of Andamans, has not been classified by IUCN due to data deficiency (IUCN, 2014). Considering the present status Lakshminarasimhan and Mondal (2012) indicated that P. santalinus is critically endangered. Similarly, Prasad et al. (2008), suggested that it is appropriate to consider $P$. dalbergioides as threatened and if not protected well, may swiftly move to the next category of extinction. In the natural habitats of Sri Lanka, the species of Pterocarpus is considered to be rare due to continuous human pressure in harvesting the trees indiscriminately (Arunakumar et al., 2011).

Among the four species mentioned above, the most important species which needs immediate attention and concern is Pterocarpus santalinus (Family: Fabaceae) an endemic species restricted to Southern parts of Eastern Ghats of India. Being a commercially important tree of Indian forests, it is popularly known as Red Sanders, Red sandalwood, Almug and Saunderswood. Red Sanders is a typical leguminous species of tropical dry deciduous forests of Andhra Pradesh being localized and predominantly confined to Cuddapah landscape between $13^{0} 30^{\prime}$ and $15^{\circ} 00^{\prime}$ North latitude and between $78^{\circ} 45^{\prime}$ and $79^{\circ} 39^{\prime}$ East longitude (Raju et al., 1999). It is distributed in an area of approximately $5160 \mathrm{~km}^{2}$ in its geographical spread of scattered forests and in elevated parts of Chittoor, Cuddapah and Nellore districts of Seshachalam hill ranges $(150$ to $900 \mathrm{~m})$. It is also found partly distributed in the Arcot and Chengalpattu districts of Tamil Nadu and also in Karnataka (GOI, 2014). It is reported that $P$. santalinus occurs in other countries like China, Pakistan, Sri Lanka and Taiwan, but must have been an introduced species (Kumar and Sane, 2003).

$P$. santalinus is a small to medium sized deciduous tree having a dense, round crown reaching a height of 10 to $15 \mathrm{~m}$ with a girth of about 90 to $160 \mathrm{~cm}$. The bark is typically dark brown in colour with rectangular plates and deeply fissured when matured. When blazed, it exudes a red colour gum with numerous pink streaks. The leaves are pinnately compound which are generally shed during January and March. With the onset of summer, new flush of leaves are produced along with large yellow coloured raceme flowers. Due to prevailing dry and hot conditions in its natural habitat, the pollination ecology is vulnerable. As an endemic species, for its continuous survival, Red Sanders has devised cross pollination as the main system exhibiting xenogamous breeding though geitonogamy exists a bit (Rao and Raju, 2002). The matured reddish brown coloured winged pods are formed after eleven months of flowering and have one or two seeds (Dayanand, 1988).

In its natural habitat, the temperature varies from a minimum of $11^{0} \mathrm{C}$ to a maximum of $46^{0} \mathrm{C}$ and rainfall varying from as low as $100 \mathrm{~mm}$ to $1,000 \mathrm{~mm}$ indicative of the excessive dry climate prevailing throughout the year. The tree prefers growing in hilly terrain and their slopes and soils in general are shallow, poor, stony and well drained. About $82 \%$ of the natural population occurs in subsurface formation of quartzites indicating the soil preference for its growth (Raju and Nagaraju, 1999). It is a heavy light demander and avoids waterlogged areas. Some of the important associated species of $P$. santalinus are Pterocarpus marsupium, Chloroxylon swietenia, Hardwickia binata, Anogeissus latifolia and Albizia lebbeck).

\section{Uses}

The sapwood is white, heartwood is red to almost purplish black with streaks (Purkayastha, 1996), the grains are interlocked, medium to fine textured, extremely strong, hard and heavy (air dried wood specific gravity ranges from 0.87 to 1.20 ) and is impregnated with reddish brown gum containing 
red dye santalin. The timber seasons well and is immune to white ants and other insects (Anonymous, 1969).

Red Sanders wood has demand both in domestic and international markets. There are two types of wood that is popular in trade, one is wavy or ripple grained and the other is straight grained. The wavy grained wood has a huge demand in the international market and is primarily exported to Japan for manufacturing a special musical instrument called as 'Shamisen' a three stringed lute used in classical music as the wavy grained wood is supposed to have superior acoustic qualities. The neck of this instrument is primarily made by Red Sanders wood. It is also used to make name seals, frames, carving and traditional dishes. The musical instruments and other objects made out of this wood have been considered as an essential dowry given in a traditional Japanese wedding (Anonymous, 2014). Historically, Red Sanders is used in China for the highly valued furniture being manufactured since tenth century. In China it is categorised under group of hardwood species designated as rosewood (Hong mu). The rosewood furniture was used by Ming and early Qing dynasties and had special cultural significance. The two groups of Rosewood Zitan and Huali are represented by Pterocarpus santalinus and Dalbergia odorifera, respectively (Wenbin and Xiufang, 2013). Buddhists prefer this wood while cremating (Ramakrishna, 1962). The straight grained wood is used for carving idols and toys. The timber is also used for house posts, agricultural implements, poles, shafts and bent rims of carts, boxes and picture frames. The leaf is used as a good fodder.

Red Sanders wood has an important insoluble or sparingly soluble red wood dye. It contains $16 \%$ of the pigment santalin (santalic acid) a major colouring matter which was first isolated in a crude form in 1833. It is being used as a textile dye and has five colouring components ranging from violet to orange in colour but is popular for providing red colour (Gulrajani et al., 2002; Siva, 2003; Ferreira et al., 2004). In European medicine, the red dye is used as a colouring agent while the French furniture makers used it for dyeing, polishing and varnishing during 1660 to 1885 (New, 1981). In USA, it is approved as a food dye for alcoholic beverages and approved as a food dye within Europe and is classified as a spice extract rather than food colourant (Mulliken and Crofton, 2008). Pterostilbene a methyl ester of resveratrol (3,5-dimethoxy-4'-hydroxy-trans-stilbene) was first isolated from Red Sanders (Sheshadri, 1972) and has wide range of promising pharmacological properties (Schmidlin et al., 2008). Arunakumar et al. (2011) have extensively reviewed the phytochemical and pharmacological uses of $P$. santalinus. An interesting study on biogeochemistry reveals that heartwood and leaf of Red Sanders have the ability for elemental association and accumulation of various elements including rare earth elements. The accumulation of various elements is higher in heartwood and the range of strontium accumulation varied from 750 to $3,500 \mathrm{ppm}$. Some of the other elements accumulated in the heartwood are cadmium (5 to $28 \mathrm{ppm}$ ), zinc (50 to 6,000 ppm), copper (105 to 1,025 ppm). Among the various rare earth elements studied, the heartwood and leaves contained an average concentration of 1.22 and $0.03 \mathrm{ppm}$ of Uranium, respectively and the accumulation was higher in P. santalinus compared to P. marsupium and P. dalbergioides (Raju and Rao, 1998; Raju and Raju, 2000; Raju and Srinivasalu, 2008). Siddhiraju (2013) reported that as $P$. santalinus has a narrow geographic and geological distribution, it can be used as a stratigraphic guide to recognize a group within the Cuddapah Super group. He also opined that all those geological formations that support the Red Sanders growth can be included under the Cheyair Group which has been abandoned by the geological survey of India in its latest classification. 


\section{Red Sanders in folklore/tribal medicine}

The heartwood has various uses in traditional medicines and is popular for the treatment of diabetes apart from other ailments. The wood paste is applied externally specially for healing various skin diseases and blemishes. Yerukula and Irula tribes of Chittoor district in Andhra Pradesh use whole plant of $P$. santalinus for ulcer treatment (Vedavathy et al., 1997). Kandhas tribe in Kandhamal district of Orissa in India use the decoction of fresh stem barks of the plant, Calamus tenuis root and Azadirachta indica stem bark being given orally either with sugar candy or honey in empty stomach for 21 days to cure piles and blood setting piles (Behera et al., 2006). It is also used by people of Assam for healing skin diseases and as cosmetics. The wood is powdered and soaked in water and the paste is applied on skin for prickly heat. For smooth and fair skin, the powdered wood is mixed with flour and egg and is applied on the body (Saikia et al., 2006). The stem bark extract is used by a tribal group of Western Ghats in Shimoga region of Karnataka state for treating diabetes, fever, snake bite and specially for Jaundice. For treating acute jaundice, about one hundred grams of powdered stem bark is boiled in $500 \mathrm{ml}$ of water for 3-4 hours till the volume is reduced to half the original content. The solution is cooled and then ten grams of jaggery is added and made into pills, two to three pills is administered every day for ten days (Manjunatha, 2006). Malamalasar tribe of Perambikulam wildlife sanctuary in Kerala considers wood paste as a blood purifier, for curing skin diseases and poisonous affections (Yeshodharan and Sujana, 2007). Tripura ethnic community in Hazarikhil, Chittagong district of Bangladesh, uses the stem sap by taking twice daily for three days to treat conjunctivitis (Faruque and Uddin, 2011). Various tribes in coastal Karnataka use Red Sanders as an anti inflammatory for the treatment of Herpes (Bhandari and Chandrashekar, 2011). Aborigines of Kalahandi, Orissa, use it as a blood purifier and diuretic. During chest pain and tuberculosis, paste is made from the wood and applied on the chest. Also solution with water is made and taken for a month orally (Panda and Padhy, 2008). Folklore claims in Assam suggest that the seeds are used in herbal formulation as an antidote against $b a b$ (the poison, the origin of which is obscure), by Karbis of Anglong district of Assam (Teron and Borthakur, 2013).

\section{Tree Improvement in Red Sanders}

Tree improvement activities in Red Sanders are similar to that of any other tree species. Two commercially important traits that are to be considered while selecting superior genotypes as well as for conservation are, (a) wavy grain genotypes and (b) deep red heartwood. Often described as 'Red Gold' and 'Pride of Andhra Pradesh', several tree improvement activities have been carried out on this endemic species by Forest Department of Andhra Pradesh. It includes, establishing seed production area, clonal orchards and having identified 25 candidate plus trees. (Reddy and Srivasuki, 1992).

\section{Studies on wavy grain}

As mentioned earlier, wavy grained wood has gained prominence because of its export value. Kedharnath et al. (1976), reported that the natural occurrence of wavy grain genotype is less than one per cent. They mentioned that tangential plane has more wavy grains than radial plane and the wood having wavy grains both tangentially and radially is valued. They also opined that waviness could be a genetic trait as wavy grain trees are seen in natural population as well as in plantations. Red Sanders has also been classified as quality and non quality variety on the basis of wavy grained and straight grained, respectively (Raju and Rao, 1987). In the field, wavy grain or straight grained trees are identified by removing a piece of bark wood such that the heartwood is visible and depending on the grain pattern, trees are designated as wavy or straight grained. 
Recognising the importance of wavy grain, and to identify, distinguish and select the wavy and straight grained trees, a scheme -Studies on the genetic basis of wavy grain in Red Sanders and methods to increase the frequency of trees with wavy grain- was initiated at Forest Research Institute, Dehra Dun. It was reported that lumen diameter was an important anatomical trait to screen for wavy grain at the sapling stage (Kedharnath and Rawat, 1976). Some of the traits differentiating the wavy grain with that of straight grain were the presence of tyrosine in the vascular cambium, pericarp venation, seed and cotyledon shape and stomatal number (Das and Dayanand, 1983; 1984). It was also found that seedlings raised from wavy grained trees were slow growing compared to that of straight grained trees. The seedlings had short internodes, smaller and greener leaves, petioles and more compact crown and concluded that these traits were distinct and can be used for segregating the seedlings (Rawat and Uniyal, 1996). Kedarnath (1984) found significant variation in waviness intensity from pith to periphery within and between trees. The physico-chemical characteristics difference revealed that wavy grained wood had 3 to $4 \%$ more of organo soluble and almost $50 \%$ less water soluble extractives compared to straight grained wood (Theagarajan et al., 2004). Raju and Srinivasalu (2008) suggested that wavy grain trees has a preference for friable soils and are absent in compact soils or soils devoid of any soil cover.

Occurrence of both normal and wavy grained trees in the similar area suggests that genetic factors play a significant role along with environmental interactions. As the numbers of wavy grained trees are low, it is possible that gene for this character must be occurring in low frequency in the population or is controlled by polygenes.

\section{Studies on vegetative propagation}

Reddy and Srivasuki (1990) have summarised the various vegetative propagation methods such as grafting, air layering and rooting of cuttings carried out by the research wing of Andhra Pradesh Forest Department. Micro propagation studies on Red Sanders began in 1980s. Various authors used different explants to arrive at suitable plantlets. Sarita et al. (1988) used single node and terminal cuttings for growing plantlets. Sita et al. (1992) induced shoots from shoot tips and successfully transferred micropropagated plants to field. Anuradha and Pullaiah (1999) reported highest shoot bud regeneration by culturing mesophyll explants. Arockiasamy et al. (2000) found that detached cotyledons from in vitro germinated seedlings were useful, while Prakash et al. (2006) used nodal explants of young shoots. In-vitro germination studies carried out by Chaturani et al. (2006) indicated that Anderson medium was ideal for its establishment and suggested that the pods must be used within one week after harvest to obtain higher germination percentage. Rajeshwari and Paliwal (2008) reported successful micropropagation protocol through auxillary shoot proliferation by using cotyledonary nodes. Nodal segments from in vitro regenerated shoots obtained from mature trees proliferated into multiple shoots (Padmalatha and Prasad, 2008). Balaraju et al. (2011) induced multiple shoots by using shoot tip explants derived from 20 days old in vivo germinated seedlings and confirmed the genetic fidelity. Warakagoda and Subasinghe (2013) studied different explants and acclimatized the in vitro rooted plants. Their technique can be used for mass propagation through micropropagation.

\section{Variability in Red Sanders}

Padmalatha and Prasad (2007) studied 16 accessions collected and found wide variation in genetic distance among the accessions as the RAPD markers reflected a high level of DNA polymorphism due to out crossing. Using molecular markers as tool, Rani and Usha (2013) have developed Sequence Characterised Amplified Region (SCAR) marker for identification of quality (wavy grain) plants at seedling stage. They found that single sharp $1 \mathrm{~kb}$ band was observed only in 
wavy grained seedlings with PTS-10 SCAR primer which was not amplified in case of non quality plants (straight grained). Jyothi et al. (2014), reported that there are differences in the genomic DNA quantity in the samples collected from different locations at Andhra Pradesh.

Significant variation was observed for height, girth and heartwood traits in a 20 year old Red Sanders plantation established in Bangalore, Karnataka. In case of heartwood content, it ranged from trees having no heartwood to trees having nearly $65 \%$ heartwood content. Similarly, in case of a 45 year old plantation, the heartwood content varied from 6.18 to $81.95 \%$ indicating the enormous variation that exists in Red Sanders which also can be useful while selecting superior genotypes (Arunkumar, 2011). Padmalatha and Prasad (2007) studied morphological variations in 16 accessions collected mostly from Andhra Pradesh and also from Karnataka and Kerala. Distinct morphological variations were observed in pod (weight, width and length) characteristics, leaf characteristics (length, width), shoot length and number of nodes in five months old germinated seedlings.

Several aspects related to tree improvement have been initiated in Red Sanders. Studies on genetic aspects related to wavy grain, heartwood variation and complete protocol for micro propagation still needs enormous refinement. Being an endemic species, efforts to extend its cultivation in different regions are already initiated.

\section{Trade in Red Sanders}

Red Sanders wood is being extensively used as a tradable commodity since $16^{\text {th }}$ century when it was being exported to European countries. It is reported that during the five years ending at 1882-83, wood exported to United Kingdom, France and Indian and Ceylon ports was 12,782, 1,116 and 1,687 tonnes, respectively, amounting to more than half a million Rupees. Observing the way it was being exploited TA Whitehead, a Forest Officer in Cuddapah wrote during the first decade of twentieth century that "not only the stems and branches but even the roots were extracted and is to be wondered at, that the tree has survived total extinction". This observation has relevance even in the present days too. As mentioned earlier, the demand for the wood is more in international market. Initially, in sixteenth century it was exported to European countries as a source for the natural dye which subsequently reduced as the synthetic dye came into the market, but Japanese merchant in 1931 approached the Forest Department of Andhra Pradesh, rekindling the wood value in the international market. Even though, $P$. santalinus has been documented in China by the Jin dynasty scholar Cui Bao (265-340 AD), it was regarded as a rare and precious lignum as expensive as gold. Presently, it costs around US\$ 150,000 per $\mathrm{m}^{3}$ (Wenbin and Xiufang, 2013). The heavy demand in international market for many centuries suggests why Red Sanders has been over exploited through illegal harvest. In its native state of Andhra Pradesh, during 2012-13, 1,488 forest offence cases have been booked for Red Sanders alone. Along with it, 1002 vehicles accounting to 1,390 tonnes of wood have been seized (Anonymous, 2014). The regular seizures of huge quantities of Red Sanders wood in international market are so common now that the survival and existence of $P$. santalinus is a cause for concern. Adding to that, the frequent changing of the smuggling routes is also a challenge and needs a constant vigilance and efforts from all the neighbouring countries where Red Sanders has huge requirement.

Considering the wood demand, restricted distribution, slow regeneration, illegal harvest, trade and habitat destruction, the species has been categorized as endangered by IUCN and has been listed in Convention on International Trade in Endangered Species of Wild Fauna and Flora (CITES). The CITES aims at ensuring the survival of wild animals and plants being traded internationally and there by safeguarding the species being over exploited. On the basis of a proposal from India, Pterocarpus 
santalinus is the only species of Pterocarpus that has been listed in Appendix II of CITES on $16^{\text {th }}$ February 1995. Appendix II includes all species which although not necessarily now threatened with extinction may become so unless trade in specimens of such species is subject to strict regulation in order to avoid utilisation incompatible with their survival. The listing was annotated to cover $-\operatorname{logs}$, wood-chips and unprocessed broken material which subsequently modified at CITES COP 14 as logs, wood-chips, powder and extracts. In Andhra Pradesh, It is protected under the Red Sanders and Sandalwood Transit Rules of the Andhra Pradesh Forest Act, 1967 and is also classified as a "reserved tree" under the Andhra Pradesh Preservation of Private Forest Rules, 1978.

\section{Future of Red Sanders}

$P$. santalinus is a resilient species and its survival amidst over exploitation from the past few centuries indicates that it is necessary to seriously think about its revival strategies. One of the best ways of conserving Red Sanders is not only to raise large scale seedling based plantations in its natural habitats but also in far away regions having similar growing conditions which would ensure that genetic material is safe for posterity. These plantations can also act as a source of plant material for initiating further tree improvement strategies. While growing Red Sanders outside the forest area, it is paramount to educate the tree growers to consider the gestation of the crop. Usually, it is a tendency among growers to compare tree growing with agricultural crops, but on a long term basis the yield and the monetary benefits accrued by growing such valuable trees are definitely high. The Government agencies must take a lead role to encourage the farmers and entrepreneurs to grow Red Sanders, as Kukrety et al. (2013) suggested that, it is imminent to have a sustainable wood trade policy formulated by strongly incorporating stakeholder's perceptions. Therefore, to revive the past glory of this valuable

species to mankind, Government agencies, farmers, entrepreneurs and policy makers have to join hands together in protecting, conserving and sustainably utilizing Red Sanders.

\section{References}

Anonymous. 1969. The wealth of India, Publication and Information Directorate, CSIR, New Delhi, India, 3: 305-306.

Anonymous. 2014. Red alert on Red Sanders: Sri Lanka apprehends large consignment from India. Traffic Post, 20: 8-9.

Anuradha, M. and Pullaiah, T. 1999. Propagation studies of Red Sanders (Pterocarpus santalinus L. f.) in vitro: An endangered taxon of Andhra Pradesh, India. Taiwania, 44: 311-24.

Arockiasamy, S., Ignacimuthu, S. and Melchias, G. 2000. Influence of growth regulators and explant type on in vitro shoot propagation and rooting of Red Sandal wood (Pterocarpus santalinus L.). Indian Journal of Experimental Biology, 38: 1270-1273.

Arunkumar, A.N. 2011. Variability studies in Pterocarpus santalinus in different aged plantations of Karnataka. My Forest, 47(4): 343-353.

Arunakumara, K.K.I.U., Walpola, B.C., Subasinghe, S. and Yoon, M.H. 2011. Pterocarpus santalinus Linn. f. (Rath handun): A review of its botany, uses, phytochemistry and pharmacology. Journal of the Korean Society for Applied Biological Chemistry, 54: 495-500.

Balaraju, K., Agastian, P., Ignacimuthu, S. and Park, K. 2011. A rapid in vitro propagation of Red Sanders (Pterocarpus santalinus L.) using shoot tip explants. Acta Physiologiae Plantarum, 33: 2501-2510.

Behera, S. K., Panda, A., Behera, S.K. and Misra, M.K. 2006. Medicinal plants used by the Kandhas of Kandhamal district of Orissa. Indian Journal of Traditional Knowledge, 5: 519-528.

Bhandari, M.J. and Chandrashekar, K. R. 2011. Herbal therapy of herpes in the ethnomedicine of coastal Karnataka. Indian Journal of Traditional Knowledge, 10(3): 528-532. 
Chaturani, G.D.G., Subasinghe, S. and Jayatilleke, M.P. 2006. In-vitro establishment, germination and growth performance of Red Sandalwood (Pterocarpus santalinus L.). Tropical Agricultural Research and Extension, 9: 116-130.

Chauhan, L. and Vijendra Rao, R. 2003. Wood anatomy of the legumes of India. Their identification, properties and uses. Bishen Singh Mahendra Pal Singh, Dehra Dun, India.

Das, T.L. and Dayanand, T. 1983. Amino acid composition in wavy-grained and straight grained trees of Red Sanders (Pterocarpus santalinus Linn. f.). Indian Journal of Forestry, 6: 158-159.

Das, T.L. and Dayanand, T. 1984. Some distinguishing characteristics between wavy grained and straight grained trees of Red Sanders Pterocarpus santalinus. Indian Journal of Forestry, 7: 6971.

Dayanand, T. 1988. Studieson development and maturity of pod in Red Sanders (Pterocarpus santalinus). Indian Journal of Forestry, 11(3): 207-208.

Faruque, O. and Uddin, S.B. 2011. Ethnodiversity of medicinal plants used by Tripura community of Hazarikhil in Chittagong district of Bangladesh. J. Taxon. Biodiv. Res., 5: 27-32.

Ferreira, E.S.B., Alison, N., Hulme, A.N., Hamish, McNab, H. and Quye, A. 2004. The natural constituents of historical textile dyes, Chemical Society Reviews, 33: 329-336.

GOI (Government of India). 2014. Government of India. Ministry of Environment of Forests Publications. Red Sanders. Available at http://moef.nic.in/downloads/public-information/Chap8-new.pdf [accessed on 24 May 2014].

Gulrajani, M.L., Bhaumik, S., Oppermann, W. and Hardtmann, G. 2002. Kinetic and thermodynamic studies on Red Sandalwood. Indian Journal of Fibre and Textile Research, 27: 91-94.

Jyothi, C.P., Chandrashekar, R. and Lakshmi, B. 2014. Isolation of Pterocarpus santalinus L. genomic DNA, for quality check and quantification with reference to Telangana region, Andhra Pradesh, India. Indian Journal of Science, 8: 21-24.

Kedharnath, S. 1984. Forest tree improvement in India. (In) Proceedings of Indian Academy of Science (Plant Science), 93: 401-412.

Kedharnath, S. and Rawat, M.S. 1976. Studies on variation in fibre morphology in wavy grained and straight grained trees of Red Sanders. Indian Forester, 102: 441-446.

Kedharnath, S., Rawat, M.S., Uniyal, D.P. and Kantham, D.L. 1976. Studies on field grafting and the growth of grafts in Red Sanders. Indian Forester, 102: 761-765.

Klitgaard, B.B. and Lavin, M. 2005. The tribe Dalbergieae sens. lat. In: G. Lewis, B. Schrire, B. MacKinder \& M. Lock (eds.), Legumes of the world. Royal Botanic Gardens Kew, London.

Kukrety, S., Jose, S. and Alavalapati, J.A.A. 2013. Exploring stakeholders' perceptions with analytic hierarchy process: A case study of Red Sanders (Pterocarpus santalinus L.) restoration in India. Restoration Ecology, 21(3): 372-379.

Kumar, S. and Sane, P.V. 2003. Legumes of South Asia, a check-list. Royal Botanic Gardens, Kew, London.

Lakshminarasimhan, P. and Mondal, M.S. 2012. A pictorial guide to some of the Indian plants included in the CITES and negative list of exports. Botanical Survey of India, Howrah, pp.22-24.

Manjunatha, B.K. 2006. Hepatoprotective activity of Pterocarpus santalinus L. f., an endangered plant. Indian Journal of Pharmacology, 38: 25-28.

Mulliken, T. and Crofton, P. 2008. Review of the status, harvest, Trade and management of seven Asian CITES-listed medicinal and aromatic plant species. http://www. cites.org/common/ com/PC/17/X-PC17-Inf-10.pdf.

New, S. 1981. The use of stain by furniture makers: 1660 to 1885. Furniture History, 17: 51-60. 
Padmalatha, K. and Prasad, M.N.V. 2007. Morphological and Molecular Diversity in Pterocarpus santalinus L.f: An endemic and endangered medicinal plant. Medicinal and Aromatic Plant Science and Biotechnology, 1: 263-273.

Padmalatha, K. and Prasad, M.N.V. 2008. In vitro plant regeneration of Pterocarpus santalinus L.f (Red Sanders): An endangered medicinal plant and important timber tree. Tree and Forestry Science and Biotechnology, 2: 1-6.

Panda, T. and Padhy, R.N. 2008. Ethnomedicinal plants used by tribes of Kalahandi district, Orissa. Indian Journal of Traditional Knowledge, 7: 242-249.

Prakash, E., Khan, P.S.S.V., Rao, T.J.V.S. and Meru, E.S. 2006. Micropropagation of Red Sanders (Pterocarpus santalinus L.) using mature nodal explants. Journal of Forest Research, 11: 329335.

Prasad, R.C.P., Reddy, C.S., Raza, S H. and Dutt, C.B.S. 2008. Population structure, age gradations, and regeneration status of Pterocarpus dalbergioides Roxb, an endemic species of Andaman Islands, India. The Pacific Journal of Science and Technology, 9: 658-664.

Purkayastha, S.K. 1996. A manual of Indian timbers. Sribhumi Publishing Company, Calcutta, India, pp.251.

Rajeswari, V. and Paliwal, K. 2008. In vitro plant regeneration of Red Sanders (Pterocarpus santalinus L.f.) from cotyledonary nodes. Indian Journal of Biotechnology, 7: 541-546.

Raju, K.K. and Nagaraju, A. 1999. Geobotany of Red Sanders (Pterocarpus santalinus): a case study from the southeastern portion of Andhra Pradesh. Environmental Geology, 37: 340-344.

Raju, K.K. and Raju, A. N. 2000. Biogeochemical investigation in south eastern Andhra Pradesh: the distribution of rare earths, thorium and uranium in plants and soils. Environmental Geology, 39(10): 1102-1106.

Raju, K.K., Raju, A.N. and Sudheer, A.S., 1999. Biogeochemistry of Red Sanders from southeastern part of Andhra Pradesh, south India. Fresenius Environmental Bulletin, 8(3-4): 204-212.

Raju, K.K. and Rao, J.R. 1988. Red Sander: An accumulator plant of Strontium, Geobios, V.15 pp. 207-209.

Raju, K.K., Rao, J.R. 1987. Distribution of Red Sanders using the geological formations in Cuddapah landscape. Indian Journal of Forestry, 10: 264- 266.

Raju, K.K. and Srinivasulu, S. 2008. The Red Sanders forestry: An environmental appraisal towards an effective legislation. Proceedings of Ecocity World Summit 2008, San Francisco, California, USA.

Ramakrishna, A. The Red Sanders and its future. Indian Forester, 88: 202-206.

Rani, J.S. and Usha, R. 2013. Development of rapd and specific scar markers for the identification of Pterocarpus santalinus. L. Journal of Cell and Tissue Research, 13(3): 3809-3816.

Rao, S.P. and Raju, A.J.S. 2002. Pollination ecology of the Red Sanders Pterocarpus santalinus (Fabaceae), an endemic and endangered tree species. Current Science, 83: 1144-1148.

Rawat, M.S. and Uniyal, D.P. 1996. Identification of wavy grained Red Sanders (Pterocarpus santalinus) at nursery state. Indian Forester, 122: 831-3.

Reddy, K.K. and Srivasuki, K.P. 1990. Vegetative propagation of Red Sanders (Pterocarpus santalinus Linn.). Indian Forester, 116: 536-40.

Reddy, K.K., Srivasuki, K.P. 1992. Biotechnological approach for tree improvement in Red Sanders. Indian Forester, 118: 15-20.

Saikia, A.P., Ryakala, V.K., Sharma, P., Goswami, P. and Bora, U. 2006. Ethnobotany of medicinal plants used by Assamese people for various skin ailments and cosmetics. Journal of Ethnopharmacology, 106: 149-157. 
Sarita, S., Bhatnagar, S.P. and Bhojwani, S.S. 1988. Preliminary investigations on micropropagation of leguminous timber tree Pterocarpus santalinus. Phytomorphology, 38: 41-45.

Saslis-Lagoudakis, C.H., Klitgaard, B.B., Forest, F., Francis, L., Savolainen, V., Williamsons, E.M. and Hawkins, J.A. 2011. The use of phylogeny to interpret cross-cultural patterns in plant use and guide medicinal plant discovery: an example from Pterocarpus (Leguminosae). PLoS ONE, 6(7): 10.1371/journal.pone.0022275.

Schmidlin, L., Poutaraud, A., Claudel, P., Mestre, P., Prado, E., Santos-Rosa, M., WiedemannMerdinoglu, S., Karst, F., Merdinoglu, D. and Hugueney, P. 2008. A stress-inducible resveratrol O-methyltransferase involved in the biosynthesis of pterostilbene in grapevine. Plant Physiol., 148(3): 1630-1639.

Seshadri, T.R. 1972. Polyphenols of Pterocarpus and Dalbergia woods. Phytochemistry, 11: 881-898.

Siddi Raju, S. 2013. Red Sanders as a stratigraphic guide in the correlation of the Cuddapah formations. International Journal of Scientific Research, 2(2): 87-89.

Sita, L.G., Sreenatha, K.S. and Sujata, S. 1992. Plantlet production from shoot tip cultures of Red Sandalwood (Pterocarpus santalinus L.). Current Science, 62: 532-535.

Siva, R. 2003. Status of natural dyes and dye-yielding plants in India. Current Science, 92: 916-925.

Teron, R. and Borthakur, S.K. 2013. Folklore claims of some medicinal plants as antidote against poisons among the Karbis of Assam, India. Pleione, 7: 346-356.

Theagarajan, K.S., Prabhu, V.V., Shankaranarayana, K.H. and Ravikumar G. 2004. Physico chemical characteristics of wavy and straight grained Red Sanders. Journal of Indian Academy of Wood Science, 1: 7-10.

Vedavathy, S., Sudhakar, A. and Mrudula, V. 1997. Tribal medicinal plants of Chittoor Ancient. Science of Life, 26: 307-331.

Warakagoda, P.S. and Subasinghe, S. 2013. In vitro propagation of Pterocarpus santalinus L. (Red Sandalwood) through tissue culture. Journal of the National Science Foundation of Sri Lanka, 41(1): 53-63.

Wenbin, H. and Xiufang, S. 2013. Tropical Hardwood Flows in China: Case Studies of Rosewood and Okoumé. Forest Trends Association, Washington DC, USA.

Yeshodharan, K. and Sujana, K.A. 2007. Ethnomedical knowledge among Malamalasar tribe of Perambikulam wildlife sanctuary, Kerala. Indian Journal of Traditional Knowledge, 6(3): 481485. 